\title{
Sex Appeal Ad and Materialism: A Comparison of Young Consumer Attitude and Purchase Intention in France and Indonesia
}

\author{
M. Gunawan Alif ${ }^{1}$, Yuniar Vigari ${ }^{2}$ \\ Sampoerna University, Indonesia ${ }^{1,2}$ \\ gunawan.alif@sampoernauniversity.ac.id ${ }^{1}$
}

\begin{abstract}
Although many studies already report on materialism or sexual appeal in advertising, this study tried to examine the direct effect and combination effect between materialism and sexual appeal to young consumers in Indonesia and France. The experimental research results showed a significant direct effect and interactions effect between sexual appeal and materialism, as well as between sexual appeal and the countries in this study. It is quite surprising to find, that the effect of high sexual appeal is greater among high materialism young consumers in Indonesia, a more religious country, compared to young consumer in more liberal France. This study explains why this kind of anomaly could happen.
\end{abstract}

Keywords Sexual Appeal, Advertising, Materialism, Attitude Toward the Ad, Attitude Toward the Brand, Purchase Intention, Indonesia, France.

\section{Introduction}

In a number of studies, sexual imagery in advertising is already considered a strong emotional appeal [1]. Sexual portrayals used in the advertising industry has been proven and tested to be provoking on how people form attitudes. It is used as powerful instrument to draw attention to a product or service.

For materialistic people, they assume the importance of possessions and acquisitions is depending as an essential prospect for the satisfaction and well-being in life. In this case, it is considered as a central place in a person's life, and is believed to be the biggest acumen of satisfaction and dissatisfaction [2].

Culturally, the appeal of sexual imagery to the audience is perceived differently in the world. In the US, some people do not like the sexy advertisements and would boycott products that have excessive sexuality in advertising [3]. However, in continental European countries (eg, Denmark, Germany, Italy, France) consumers are generally not too concerned against nudity or voluptuousness in advertisements [4]. In France, some sexual ads even have some sort of understanding that is not always negative and is referred only as "porno-chic" [5]. French women generally consider nudity and sexuality of women more as an aesthetic rather than sexist [6].

As [7] mention that attitude toward the ad and attitude toward the brand will positively affecting purchase intention, this study will seek what is the effect of sexual appeal advertising, materialism, and different culture, regarding attitude toward the advertising, attitude toward the brand and purchase intention. This study will involve young consumer in 
Indonesia and French, two countries with different norms and culture, especially regarding sexual matters. Furthermore, this study contributes to the literature by demonstrating how sexual appeal and materialism as a cultural or structural variable together affecting young consumer in two different countries who have different norms and culture of consumption.

\section{Literature Review}

\subsection{Sexual Appeal in Advertising}

Several previous studies have found that the number of sexually-themed advertisements continue to evolve over time. [8] states that the use of sexual content in the suggestive forms, nudity, sexual situations and behaviors are more frequently used to sell products to teenagers and young adults. Moreover, [9] also stated that during the last two decades, the use of sexual imagery in print advertising has become mundane. This happens because the advertisers are competing to break through the clutter, and they take the advantage of the unusual imaging techniques such as advertisements with sexual portrayals [7].

Representation of sexy and attractive models in advertising can also act as an intermediary in strengthening and reshaping the norms and beliefs in society, especially in appreciating that life will feel good and comfortable through the depiction of sexuality [10]. [11], [12] even found that sexual imagery can even lead to a superior attitude and purchase intention.

On the contrary, a number of relevant literatures [13], [14] showed that the sexual advertisements clearly contribute to gender inequality by promoting the creation of "sexism" and distorted body image as valid and acceptable. In this case, sexism refers to the portrayal of women and men who are relatively considered inferior than their abilities and potentials.

[15] found that women in the UK tend to be depicted in a decorative role, especially with "physical attractiveness" and "sex object". The same trend was also reflected in a study conducted in Germany, Greece, the Netherlands, Sweden and the United States, which reported an increase in the use of the portrayals of physical attractiveness and sexual object to illustrate women in print ads [16]. In Indonesia, [17] found that women in advertising pictured in five frames as beauty, feminine, sexual objects, domestic workers, and intermingle.

\subsection{Sexuality among Cultures}

Many cross-cultural studies have revealed that in a number of different countries the roles of women are also depicted differently in the advertisements (Nilaweera and Wijetunga 2005). Study of [18] compared the image of female nudity in advertising in Germany and the US magazine in 1986, 1989 and 1992. They found the shift of the image section which is applied from time to time, ranging from the use of clothing that openly and show parts of naked body, to a more suggestive image of dress, such as an open blouse or tight clothing. They have found that advertisements containing nudity in Germany turned out to be less than in US. [19] compared the use of sexual imagery in advertising in the United States and French print ads in news and women's magazines. They found the French advertising uses more sex imagery than American advertisements. Additionally, women also used more frequently than men in sexual advertisements in France compared to the United States.

The effect of culture or nationality on the sexual portrayals appears in advertising.[20], who studied award winning advertising Clio Awards, found that the local norms are reflected in most of the advertising domestic product, while "Western" image or global norms are more dominant in international advertising products. [21] compared the image of women in women's magazines in India and reported that White model or Western models were more often placed as sex kitten/sensual role in advertising than were their Indian counterparts. 
Similarly, in a comparison of Western and Asian models in Singapore, Taiwan, and the United States, [22] reported that the images of sensual or sexual beauty employed more Western models than Asian models. There is usually a restriction placed for the portrayal of indigenous women than foreign women. For example, in Malaysia, the rules are different for portrayal of Muslim women compared to White models or Western women [4]. However, ads in Thailand and France had showed the highest level of sexuality, regardless of whether the advertisements used domestic or non-domestic models, or whether the ad was promoting domestic or international products [23], despite a study that found the depiction of nudity has become similar to the Western model and the Chinese model in China [24].

\subsection{Materialism}

Materialism is raising in-line with real incomes and an abundance of consumer goods that have made materialism possible. [25] concluded, besides cultural and historical differences in the tendency toward materialism, there are also individual differences in the manifestations of materialism.

[26] explained that materialism refers to a "devotion to material needs and desires, to the neglect of spiritual matters; a way of life, opinion, or tendency based entirely upon material interests," as defined in the Oxford English Dictionary. [2] defines materialism as: "The importance a consumer attaches to worldly possessions. At the highest levels of materialism, such possessions assume a central place in a person's life and are believed to provide the greatest sources of satisfaction and dissatisfaction."

Materialism itself could become bad or good depending on the purpose of consumption. When people only act as an essential means for discovering and furthering personal values and goals of life, the materialism in this case is potentially a harmless form. This kind of materialism is labeled as "instrumental materialism." But consumption could further beyond possession itself, then the materialism is regarded as a more dangerous form and labeled "terminal." [27] found materialistic individuals form strong connections to their brands as a response to existential insecurity.

[25] explained about possessiveness, non-generosity and envy in measuring materialism. He defined possessiveness as "the inclination and tendency to retain control or ownership of one's possessions." Non-generosity is "an unwillingness to give possessions to or share possessions with others." Then envy has been defined as "displeasure and ill will at the superiority of another person in happiness, success, reputation, or the possession of anything desirable."

We could see materialism is mostly about acquisition and possession. Materialists place possessions and their acquisition at the center of their lives. More than that, possessions and their acquisition are so central to materialists because they view these as essential to their satisfaction and well-being in life. Materialists also tend to judge their own and others' success by the number and quality of possessions accumulated [28].

Study from [29] examines whether consumption increases the desired positive feelings among materialists in the short term. Their results suggest that consumption didn't leads to more positive feelings among materialists than it does among consumers low in materialism. Furthermore, materialists experience stronger negative feelings after acquisition than do consumers low in materialism.

Development of materialism for young consumer is mainly based on socialization. The sources of socialization may be peers, mass media and the family [30]. [31] explains that the mass media like television is reported to be instrumental in socializing consumers into materialism. Heavy viewing of television can also foster the development of materialistic 
values through TV advertisements' consistent conveyances of messages that project products as solutions to problems. Some advertisements creatively persuade viewers to think that selfworth can be gained from possessions.

\section{Method and Hypotheses}

\subsection{Hypotheses}

Materialism is about possession and acquisition [28], and also involving non-generosity and envy [25]. Materialistic individual would make strong bonding to the brand because of insecurity [27].

Hypothesis 1a: Young consumer with high materialism will have more positive attitude toward the ad, attitude toward the brand, and purchase intention with high sexual appeal ad compared to young consumer with low materialism.

Hypothesis 1b: Young consumer with high materialism will have more positive attitude toward the ad, attitude toward the brand, and purchase intention with high sexual appeal ad compared to low sexual ad.

Sexual themed advertisements are common in the countries where the societies are more liberal [7], compared to more religious countries [4].

Hypothesis 2: Sexual appeal advertising will brings more positive attitude toward the ad, attitude toward the brand, and purchase intention for young consumer in French compared to young consumer in Indonesia.

\subsection{Method}

To test the hypotheses, this study utilize 2 sexual appeal ads (high, low) x 2 materialism scale (high, low) x 2 countries (Indonesia, France) between subject experimental design. The main study conducted in France, and Indonesia.

The sample for this study was a convenience sample for generating ideas, insight or hypothesis [32]. The sample consisted of undergraduate students from two universities in Greater Jakarta, Indonesia, and one university with campus in Paris and Lille, France. While this sampling method inevitably limits the external validity of the findings, careful selection of products specifically relevant to that population was deemed an appropriate means to maximize its internal validity.

Pilot test with 50 subjects similar with target sample was conducted in Jakarta to choose the product and high sexual appeal and low sexual appeal ad. Due to accessibility, the same pilot test is not done in France. The product chosen is a lollypop candy, a low involvement product that common for young consumer and easy for them to buy. To test sexual appeal and product congruence, subjects should made agreement (yes or no) about relevancy to use sexual appeal ad for lollypop candy. Agreement for this sexual appeal and product congruence is 88 percent. The candy brand name is fictitious to eliminate the brand effect in the experiment. To enlarge external validity to complement with realism and generalizability, the ad stimuli were actual full page, color print ads from an existing lollypop brand that available in internet. The ad only consists of sexual visualization and brand name, indefinitely will help to focus on sexual predictive effect without other extraneous bias.

Materialism scale was measured using 18 items scale of [28], then divided into high and low materialism consumer through median. Dependent variables are attitude toward the ad with six items [33], attitude toward the brand with three items (Chattopadhyay and Basu 1990), and purchase intention with two items [34]. All items measured with six Likert type scale. 
All measurements have good reliability tests, with Cronbach Alpha for materialism 0.815; attitude toward the ad 0.839; attitude toward the brand 0.904; and purchase intention 0.729 . Validity tests have same results with all items of measurement have KMO value and factor loading bigger than 0.5 .

Subject of this study is young adult consumer in Indonesia and France between 18-30 years old. The sample consists of 272 male and female which live in Jakarta, Indonesia, and Paris and Lille, France. In this experiment 139 participants are young consumers in Indonesia, and another 133 subjects are young consumers in France. Although this study used convenience sampling to get the participants, all subjects were randomly allocate to each cells of the experiment to minimize extraneous bias. The researcher gave an introduction and the purpose of the study to measure subject opinion on a new brand of candy that in the process of production and launching. After explained on how to fill the questionnaire, the participants could see the ad based on their cells treatment, high or low sexual appeal ad. In the last part of the questionnaire, the respondents were pleased to fill questions about the demographical data. At the very end of questioner there is manipulation check to make sure subject understand what kind of ad that they are measured.

\section{Result}

Not less than 272 participants, divided equally among gender, involved in this research, 139 representing Indonesia and 133 from France. All of them like a candy: 74 subjects like a lot and the rest like fairly. Participants' age in Indonesia is in 18-22 years old brackets (61\%); $23-26$ years (37\%); and 27-30 years (2\%); and in France is in 18-22 years (59\%); 23-26 years (37\%); and 27-30 years (4\%). Manipulation check found that all participants correctly mention that the advertisement is for a lollypop candy with a brand name Candy Chup.

Table 1 shows the descriptive mean and standard deviation at every cells treatment.

Table 1. Descriptive Mean and Standard Deviation

\begin{tabular}{|c|c|c|c|c|}
\hline & \multicolumn{2}{|c|}{ Materialism High } & \multicolumn{2}{|c|}{ Materialism Low } \\
\hline & Sexual Ad High & Sexual Ad Low & Sexual Ad High & Sexual Ad Low \\
\hline \multirow[t]{3}{*}{ Indonesia } & Aad 3.69 (1.187) & Aad $3.64(.760)$ & Aad $3.35(.871)$ & Aad 3.35 ( . .584) \\
\hline & $\mathrm{AaB} 4.44(.769)$ & $\mathrm{AaB} 3.99(.716)$ & $\mathrm{AaB} 4.10(.547)$ & $\mathrm{AaB} 3.87(.544)$ \\
\hline & PI $3.91(.957)$ & PI $3.30(.964)$ & PI $3.53(.593)$ & PI $3.27(.560)$ \\
\hline \multirow[t]{3}{*}{ France } & Aad $3.56(.584)$ & Aad $3.69(.850)$ & Aad 3.27 ( .676) & Aad $3.24(.797)$ \\
\hline & $\mathrm{AaB} 4.17(.526)$ & $\mathrm{AaB} 4.19$ ( .677) & $\mathrm{AaB} 4.11 \quad(.468)$ & $\mathrm{AaB} 3.84 \quad(.613)$ \\
\hline & PI $3.47(.499)$ & PI $3.52(.870)$ & PI $3.42 \quad(.442)$ & PI $3.12 \quad(.740)$ \\
\hline
\end{tabular}

One way Analysis of Variance (ANOVA) shows significant different results among cells treatment: attitude toward the ad $(\mathrm{p}<0.1 ; \mathrm{F}=1.897)$; attitude toward the brand $(\mathrm{p}<0.01$; $\mathrm{F}=3.383)$; and purchase intention $(\mathrm{p}<0.01 ; \mathrm{F}=3.452)$.

Regarding attitude toward the ad, there is a significant materialism effect when subjects seeing high sexual appeal ad. Indonesian high materialism subjects have more positive attitude toward the ad compared to low materialism subjects $(\mathrm{p}<0.1 ; \mathrm{t}=1.764)$, and also the same for France's subjects $(\mathrm{p}<0.1 ; \mathrm{t}=1.881)$. But there is no materialism effect for low sexual appeal ad in Indonesia or in France. Materialism effect also significantly affect attitude toward the brand. Indonesian high materialism subjects have more positive attitude toward the brand compared to low materialism subjects $(\mathrm{p}<0.05 ; \mathrm{t}=2.269)$. Also high materialism subject significantly prefer high sexual appeal ad than low sexual appeal ad $(p<0.01 ; t=3.040)$. On the contrary, this finding is different for France subject that does not have any significant results. 
The same materialism effect also happens in purchase intention. Indonesian high materialism subjects have more positive purchase intention compared to low materialism subjects $(\mathrm{p}<0.05 ; \mathrm{t}=2.162)$, and high materialism subject significantly prefer to purchase product in high sexual appeal ad than low sexual appeal ad $(\mathrm{p}<0.01 ; \mathrm{t}=3.452)$. This kind of difference also did not happen in France subjects. All of the means effects attitude toward the ad (AAD), attitude toward the brand $(\mathrm{AAB})$ and purchase intention (PI) were presented at Figure-1. Based on this finding, hypothesis $1 \mathrm{a}$ and $1 \mathrm{~b}$ only partially supported. The hypothesis only fully supported for Indonesian subjects but not for France subjects.

From Figure-1 we could see that all measured response to high sexual appeal ad is higher at the high materialism condition, with Indonesian subjects have more positive response. For Indonesian subjects all of materialism effect when seeing high sexual appeal ad is significant, but not for France subjects that only significant for attitude toward the ad. On the contrary, there is no significant effect of materialism for Indonesian subjects who seeing low sexual appeal ad, but

all of measurements are significant for France subjects (AAD: $p<0.05, t=2.257$; AAB: $\mathrm{p}<0.05$, $\mathrm{t}=2.333$; PI: $\mathrm{p}<0.05, \mathrm{t}=2.174)$. High materialism France subjects will response more positive to low sexual appeal compared to low materialism subjects.
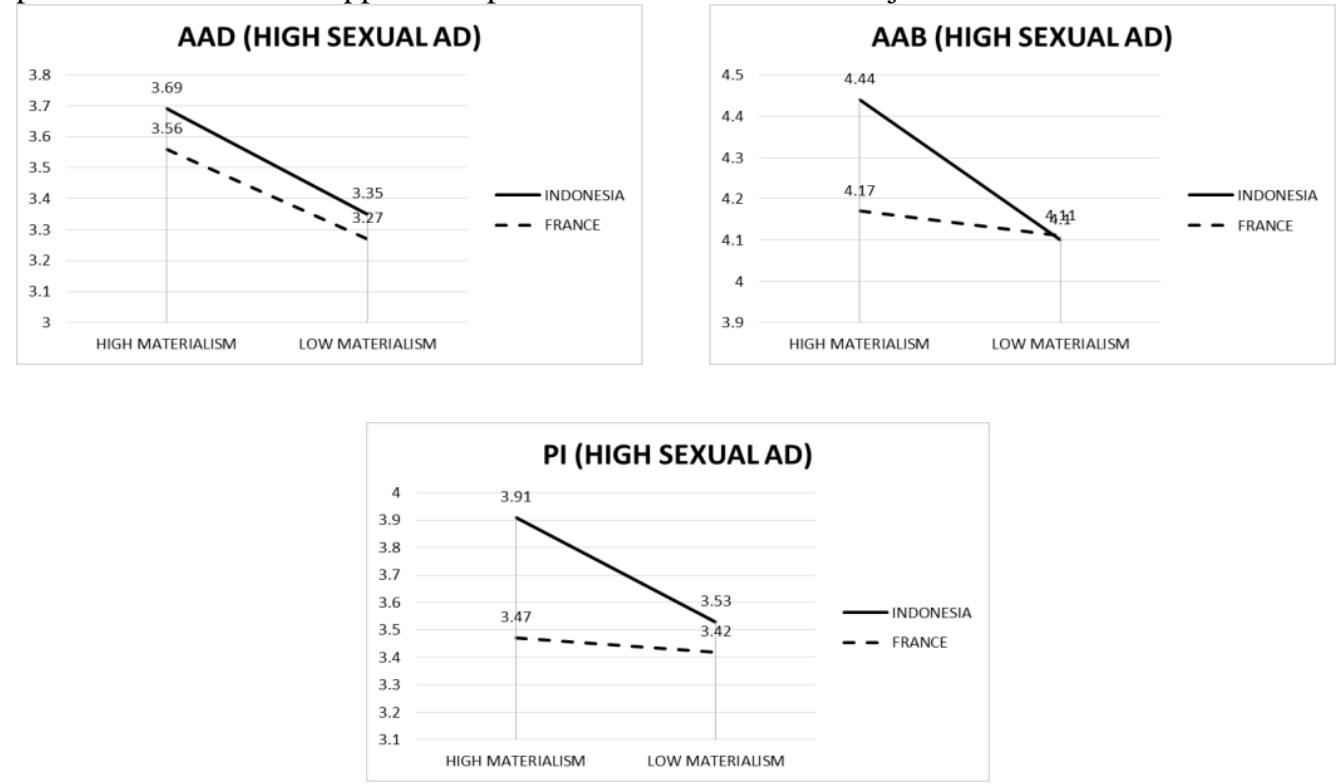

Fig. 1. Response toward high sexual appeal ad for attitude toward the ad (AAD), attitude toward the brand (AAB) and purchase intention (PI).

This result shows that Indonesian high materialism would be more positive to response to high sexual appeal ad than low sexual appeal ad.

In low materialism consumer there is no different effect regarding high sexual appeal ad toward attitude toward the ad, attitude toward the brand and purchase intention among young consumer in Indonesia and France $(\mathrm{AaD}: \mathrm{p}=0.679, \mathrm{t}=0.688 ; \mathrm{AB}: 0.948, \mathrm{t}=-0.065$; PI: $\mathrm{p}=0.554, \mathrm{t}=0.593)$. 

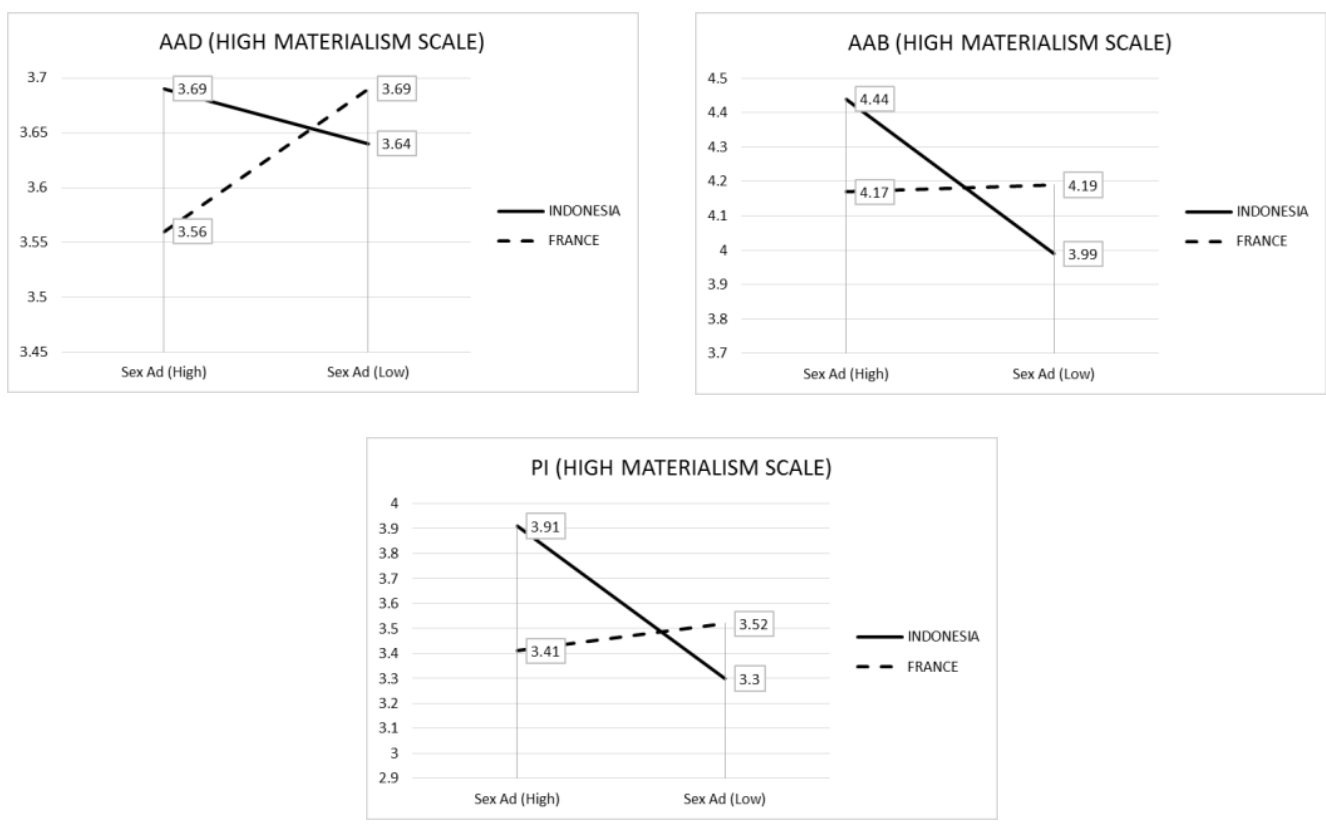

Fig. 2. Response toward high materialism consumer for attitude toward the ad (AAD), attitude toward the brand (AAB) and purchase intention (PI).

Furthermore, the result of comparing the young consumer from Indonesia with France in high materialism condition shows that young consumer in Indonesia have same attitude toward the ad with their colleagues in France $(\mathrm{p}=0.492, \mathrm{t}=0.688)$. Although there is a significant different for attitude toward the brand $(\mathrm{p}<0.1 ; \mathrm{t}=1.820)$, and purchase intention $(\mathrm{p}<0.01 ; \mathrm{t}=2.807)$, with higher positive response for Indonesian subjects. This outcome is against the hypothesis 2 that stated young consumer in France will response more positive to high sexual appeal ad compare to Indonesian.

As we could see in Figure-2, Indonesian subjects in high materialism condition have higher positive response toward attitude toward the ad, attitude toward the brand, and purchase intention when seeing high sexual appeal ad compared to France subjects. On the contrary, Indonesian has lower response in low materialism condition.

Additionally, Multi Variate Analysis of Variance (MANOVA) is used to check the interaction effect among the independent variables. The results show significant level $(\mathrm{p}<0.01)$ with Pillay's Trace; Wilks' Lambda; Hotelling's Trace and Roy's Largest Root; for interaction effect of sexual appeal and country. The same significant interaction effect $(\mathrm{p}<0.01)$ also happen to sexual appeal and materialism. However, the interaction effect of country and materialism is only significant based on Roy's Largest Root $(p<0.05)$, but not for other measurements ( $>0.1)$. This is the reason there is no interaction effect for all three variables: country, sexual appeal and materialism.

To conclude, the outcome of MANOVA is confirming that there is a significant support regarding the construct of this study about the combination effect of country, sexual appeal, and materialism.

As a final point, following Belch \& Belch (2015), regression analysis also demonstrate that attitude toward the ad and attitude toward the brand is positively affecting the purchase intention $(\mathrm{p}<0.001, \mathrm{~F}=77.500, \mathrm{VIF}=1.098)$. 
The regression equation is: $\mathrm{PI}=0.275+0.118 \mathrm{AAD}+0.613 \mathrm{AAB}$

(AAD: $\mathrm{p}<0.001, \mathrm{t}=3.988$; $\mathrm{AAB}: \mathrm{p}<0.001, \mathrm{t}=10.065$ ). Regression analysis using each of country data also brings the same effect, in line with theory that attitude toward the brand has a bigger effect to purchase intention. Beside this multiple regression analysis result, together with ANOVA and MANOVA outcomes, this study passed the appropriate statistical test.

\section{Discussion}

Sexual appeal advertisement and materialism in two different countries that have different norms and culture, by investigating young consumer in Indonesia and France. It is found that there is a significant interaction effect of sexual appeal and country, as well as sexual appeal and materialism. This study concludes about materialism effect in favoring high sexual appeal advertisement. All measurements show higher response to high sexual appeal ad in high materialism condition. It is significantly different for Indonesian subjects, but this effect is not significant for attitude toward the brand and purchase intention for France subjects. In contrast, high materialism France subjects in this study prefers low sexual appeal ad compared to low materialism subjects. This result is against literatures that mention more liberal the country, more common the sexual themed advertisements [7] and as [6] elaborate, more permissive to sexual presentation. Especially when compared it to more religious countries [4].

The result becoming more interesting when Indonesia is more religious country compared to France, as in Indonesia 99 percent of the population considering religion is important, but only 29.5 percent population in France favor the same (www.nationmaster.com). Also as [35] explain, Hofstede masculinity/femininity dimension predictability has an impact on sex role. Both countries were in the same feminine countries in Hofstede Masculinity Cultural Dimension (Indonesia=46; France=43). A low score (below 50) on this Hofstede dimension means that the dominant values in society are caring for others and quality of life. A Feminine society is one where quality of life is the sign of success and standing out from the crowd is not admirable [36].

To explain this extra ordinary result we should see the history of sexual appeal presentation in these two countries. Many studies show that sexual advertising is becoming common and usual in France [4]-[6]. This is possibly the reason consumer in France did not give further response to sexual appeal advertisement. They feel much too common for sexual imagery because they had exposed to sexual theme much longer compared to the Indonesian.

In contrast, expose to sexual appeal in Indonesia only happened after the Indonesian reform in 1998 when management of media gradually more liberal. Prior to that year Indonesian government was strictly controlled the circulation and content of the media, and did not allow high sexual appeal ads. In line with reform, the Indonesia Press Law No. 40/1999 gives the possibility to publish print media without government permission. It was creating many prints media in the market, and some were competing to attract the reader's attention through sexually attractive news. Men's magazines such as Popular, FHM, and Maxim began to circulate in the market. Many popular magazines with sexual appeal portrayals like Cosmopolitan, Elle, Harper's Bazaar, and Vogue were also flourishing in Indonesia [37].

Exposure to sexual appeal also happen in television that likewise flourished from only five national channels to 11, five cable/pay TV, plus hundreds of local broadcasters. With bigger penetration of internet on laptop or smartphone (Alif, 2014), exposure to sexual presentation becomes easier. Especially for teens and young adults who are digital natives. 
This phenomenon is similar to what happened in Turkey, which has higher materialistic scale, compared to Europeans and Americans samples in [38]. Although in discussion of the study they do not really believe all of this happens because the economic affluence and Western culture; or that materialism is on the rise in the developing countries, we could say it is the explanation for what occurs in Indonesia.

With more freedom to behave after reform, the young consumer could choose whatever they like, from tattoo and piercing (both before reform are banned), as well as to consume sexual imagery in prints, television and mostly internet.

Within this condition, young consumer openly and secretly is starting to look for sexual presentation, especially in internet. As today's youth are more mature, media-savvy, and culturally experienced than past generations, [39] found that the girls in their study had clearly defined conceptions of the models in the advertisement. The ability of these young females to read the cultural nuances of advertising (i.e. exotic or sexy) was quite developed.

As young consumer decisions are made automatically and unconsciously, judgments are also made quickly and automatically, driven by emotions and gut feelings. Studies show materialistic individuals have been found to have lower levels of satisfaction with their lives in general and with their standard of living in particular [40], [41] because they have high and unrealistic desires and thus expect more from the products. As [42] explain, individuals seek to alleviate existential anxiety by conforming to dominant cultural worldviews, which in advanced consumer societies includes the acquisition of material objects.

Considering this discussion, in the condition of materialism and sexual appeal we could conclude and explain why the high materialism young consumer in Indonesia behave differently with their peers in France, to positively prefer high sexual appeal ads.

\subsection{Limitations and Future Research Directions}

materialism and sexual appeal, this study naturally entails a variety of limitations, many of which point to interesting issues for future research.

Although pilot test and manipulation check was done carefully, possible misconduct still happens. This study used lollypop candy, a low involvement and easy to buy products. Albeit all of the subjects in the experiment like a candy a lot or fairly, unfortunately this research did not make a pilot test to check if there is any different preferential regarding lollypop candy among subjects. Arguably, this lollypop preference test possibly could bring different effect.

This study only made a single manipulation advertisement treatment in the experiment that equivocally will much better with more stimuli. Furthermore this study conducted at Greater Jakarta, Indonesia, and Paris and Lille in France. The result could also be different if the same experiment is done in small cities or rural areas in Indonesia. This would be an interesting study to thoroughly understand whether the results of this study can be generalized to the entire Indonesia.

To further test the effect of sexual appeal and materialism, supplementary studies on this subject could be completed with more variation of product category such as utilitarian or hedonic products, or for durable and high involvement products. In such a way we can truly understand the impact and interaction effect of sexual appeal and materialism in the mind of consumer.

\section{References}

[1] S. Putrevu, "Consumer Responses Toward Sexual and Non Sexual Appeals, the Influence of Involvement, Need for Cognition (NFC), and Gender," J. Advert., vol. 37, no. 2, pp. 57-69. 
[2] R. W. Belk, "Three Scales to Measure Constructs Related to Materialism: Reliability, Validity, and Relationships to Measures of Happiness,"," in Advances in Consumer Research, vol. 11, T. Kinnear, Ed. Provo, UT, p. 297.

[3] J. Fetto, "Where's the Lovin?," Am. Demogr., vol. 23, pp. 10-11.

[4] K. T. Frith and B. Mueller, Advertising and society: Global issues. New York: Peter Lang.

[5] B. Mueller, Dynamics of International Advertising: Theoretical and Practical Perspectives. New York: Peter Lang.

[6] T.-D. E. Delphine Manceau, "Female Nudity in Advertising: What Do French Women Think?," in Gender and Consumer Behavior Volume 6, eds. Pauline Maclaran, Paris, France: Association for Consumer Research, Pages, pp. 85-109.

[7] G. E. Belch and M.A.Belch, "No Title," in Advertising and Promotion: An Integrated Marketing,

[8] T. Reichert, "Examination of Brands and Content Characteristics of Ads Rated Most Sexual By Young Adults," Bus. Res. Yearb. Glob. Bus. Perspect., pp. 8-41.

[9] M. Latour and R. E. P. and David C. Snook-Luther, Female Nudity. Arousal, and.

[10] M. C. Martin and J. W.Gentry, Stuck in the Model Trap. The Effects of Beautiful.

[11] R. Vezina and O.Paul, "No Title," in Provocation in Advertising: A Conceptualization and An Empirical, .

[12] K. Hyllegard and J. O. and Ruoh-Nan Yan, "The impact of advertising message strategy - fair labour v. sexual appeal - upon Gen Y consumers' intent to patronize an apparel retailer," J. Fash. Mark. Manag. An Int. J., vol. 13, pp. 109-127.

[13] M. M. Lazar, "'Discover the power of femininity!' Analyzing global 'power femininity' in local advertising," Fem. Media Stud., vol. 6, no. 4, pp. 505-517.

[14] J. Kilbourne, Can't buy my love: How advertising changes the way we think and feel. New York: Simon \& Schuster.

[15] S. Lysonski, "Role Portrayals," in British Magazine Advertisement, European Journal.

[16] D. Gauntlett, Media, Gender and Identity: An Introduction. London: Routledge.

[17] T. A. Tomagola, "” Advertising Image of Women," in Indonesian Magazine: An, .

[18] F. Piron and M. and Young, "Consumer advertising in Germany and the United States: A Study of sexual explicitness and cross-gender contact," J. Int. Consum. Mark., vol. 8, no. 3/4, pp. 211-228.

[19] A. Biswas, J. E. Olsen, and and Valerie Carlet, "A Comparison of Print Advertisements from.".

[20] L. N. Reid, C. T. Salmon, and L. C. and Soley, "The nature of sexual content." .

[21] K. Karan, "Advertising and the visual portrayal of the modern Indian 'stereotypes.' Paper presented at the annual meeting," in of the International Communication Association, San Diego, CA.

[22] K. T. Frith, H. Cheng, and P. Shaw, Race and beauty: A comparison of Asian and. Western.

[23] M. R. Nelson and H.-J. Paek, "Cross-Cultural Differences in Sexual Advertising Content in a Transnational Women's," Mag. Sex Roles, vol. 53, no. 5, pp. 371-383.

[24] Y. Huang and D. T.Lowry, "An Analysis of Nudity," in Chinese Magazine Advertising,

[25] R. W. Belk, "Materialism: Trait aspects of living in the material world," J. Consum. Res., vol. 12, no. 3, pp. 265-280.

[26] M. L. Richins and S. Dawson, "A Consumer Values Orientation for Materialism and Its Measurement: ScaleDevelopment and Validation,” J. Consum. Res., vol. 19, pp. 303 
316.

[27] A. Rindfleisch, J. E. Burrough, and and Nancy Wong, "The Safety of Objects: Materialism, Existential Insecurity, and Brand Connection," J. Consum. Res., vol. 36, pp. 1-16.

[28] M. L. Richins, Dawson, and S., "A consumer values orientation for materialism and its measurement: Scale development and validation," J. Consum. Res., vol. 19, no. 3, pp. 303-316.

[29] M. L. Richins, K. K. R. McKeage, and and Debbie Najjar, “'An Exploration of Materialism and Consumption-Related Affect," in NA - Advances in Consumer Research Volume, vol. 19, J. John F. Sherry and B. Sternthal, Eds. Provo, UT: Association for Consumer Research, Pages, pp. 229-236.

[30] S. Benmoyal-Bouzaglo and G. P. Moschis, "Effects of Family Structure and Socialization on Materialism: A life Course Study in," Fr. J. Mark. Theory Pract., vol. 18 , no. 1 , pp. $55-71$.

[31] H. I. Duh, "Antecedents and Consequences of," in Materialism: An Integrated Theoretical, .

[32] N. K. Malhotra, "No Title," Mark. Res. An Appl. Orientat.

[33] R. N. Laczniak and D. D., "No Title," in The Relationship Between Experimental, .

[34] C. Okechuku and G. Wang, "The Effectiveness of Chinese Print Advertisements in," North Am. J. Advert. Res., vol. 28, pp. 25-34.

[35] A. M. Soares, "Minoo Farhangmehr and Aviv Shoham," J. Bus. Res., vol. 60, pp. 277284.

[36] G. Hofstede, Culture's Consequences; Comparing values, behaviors, institutions and organizations across nations, 2 nd ed. ). Thousand. Oaks, CA: Sage.

[37] M. G. Alif, "Advertising Growth in Indonesia: an Effort to Build A Reputation."

[38] G. Ger and R. W.Belk, "No Title," in Measuring and Comparing Materialism CrossCulturally, .

[39] M. C. Martin and Peters, "Exploring Adolescent Girls'," Identif. Beauty Types.

[40] M. L. Richins, "Media, Materialism, and Human Happiness," in Advances in Consumer, .

[41] M. J. Sirgy, "Materialism and Quality of Life," Soc. Indic. Res., vol. 43, pp. 227-260.

[42] J. Arndt, S. Solomon, T. Kasser, and and Kennon M. Sheldon, "The Urge to Splurge: A Terror Management Theory Account of Materialism and Consumer Behavior," J. Consum. Psychol., vol. 14, no. 3, pp. 198-212. 